\title{
The Space Between: Land Claims and the Law in Indonesia
}

\author{
Laurens Bakker and Sandra Moniaga \\ Radboud University Nijmegen and Van Vollenhoven Institute, Leiden University
}

\begin{abstract}
In this article we look at rights discourses and law as an arena of struggle in which local people attempt to gain and secure access to localities of value. Following administrative decentralisation in 1999, throughout Indonesia, individuals and communities lodged land claims. To support these claims, multiple sources of legitimation were used. Among others: customary rights; a history of using the land; or official land law. We focus on the interaction between these groups and the government officials whose authority is required to grant access. We look at conflicts, as well as alliances, in nine different settings and discern three basic constellations through which legitimation is sought: (1) national state institutions; (2) regional autonomy opportunities; and (3) extra-legal arrangements. We find that the lowest levels of government offer the best chances of success but that security increases with higher levels of ratification. We show that broad alliances present an efficient strategy to gain rights to land and that it is vital for local communities to include government bodies, or capture official law's agency.
\end{abstract}

\section{Keywords}

land, natural resources, forest, law, indigenous peoples, Indonesia, resistance, Kalimantan, Java, Sumatra, Sulawesi, indigenous rights

\section{Rights and Disputes}

When Suharto stepped down as president of Indonesia in 1998, more than three decades of centralised New Order rule and authoritarianism came to an end. ${ }^{1}$ Hope and uncertainty mixed as politicians, elites and common people did not quite know what the state's future had in store. Throughout the nation, people called for greater democracy and an end to New Order authoritarianism. Successive new governments addressed this issue by decentralising considerable administrative authorities from the central to the regional levels.

1 Research for this paper was carried out in Mentawai and East Kalimantan (Bakker) and in Java and Sulawesi (Moniaga). We are grateful to Myrna Safitri and Rudi Syaf for firsthand information on Lampung and Jambi respectively. 
This decentralisation of authority caused an upsurge of claims by local people to land, forest and other natural resources. Local authorities were within the reach of the population and were perceived by them as empowered to adjudicate such matters. Claims varied in scope and argumentation. They could be individual or collective, based on such diverse grounds as prior occupancy, traditional rights (adat) or on reinterpretation of colonial law. All of these grounds have a foundation in Indonesian land law but definitions, subjects or derivable rights are poorly understood by most Indonesians.

Although the primary purpose of law is to provide certainty, the current practice of Indonesia's land law does not create this. Land law provides guidelines but its interpretations are diverse and implementation at the local level varies. In this article we look at the discourses and claiming processes that occurred in various areas of Indonesia between 1998 and 2009. We want to see how people deal with the inherent uncertainty and dynamics of competing claims and exploit the ambiguity between guidelines, interpretations and implementation of laws. We are concerned with the strategic opportunities that weak local government, strong adat, and post-Suharto legal change offer to people who claim land and seek negotiation rather than open conflict.

\section{Official Land Rights and Adat}

Access to land in Indonesia is regulated mainly by the Basic Agrarian Law (BAL) and the Forestry Law, which govern land and forest areas respectively. ${ }^{2}$ The BAL was supposed to combine the best of 'modern law' (rule-based and nationwide applicability) with the recognition of the social function and mutual cooperation inherent in 'traditional tenure systems' (adat). Article six, for instance, decrees that land must be related to its social function (cf. Fitzpatrick, 1999:75-76). This article was frequently used to justify government land acquisition but was also a ground for the poor to demand social and environmental justice in land allocation and legally-defended land (re)occupations (Sangaji, 2000; Bachriadi and Lucas, 2002; Lucas and Warren, 2003).

The BAL nominally recognises adat land claims. The underlying assumption to this recognition was that national land law, as a uniform and unique Indonesian system, would ultimately replace adat (see Supomo, 1953). Private

\footnotetext{
2 We refer to 'forest area' rather than 'forest land' as the translation of kawasan hutan. Legally, land is under the jurisdiction of the National Land Agency, while the Forestry Department has the authority to manage such forest resources as exist in forest areas. See Moniaga (2006) for a more elaborate discussion on the limits of the authority of the BAL and the overruling application of the Forestry Law.
} 
land rights require registration and certification by the National Land Agency (NLA) - a decentralised organ responsible for enforcing the BAL — to be valid. Adat rights can be registered but only after re-interpretation as private land rights. The state has the right to dispossess land for the national or public interest in exchange for suitable indemnification.

Control over forest areas lies solely with the state, represented by the Forestry Department. ${ }^{3}$ The Forestry Law discerns between state forest where no private rights can be established and private forests where this is possible. Customary claims are classified as state forest and can only be recognised if found to be 'still relevant' and 'not conflicting with national interests'. The vague definition of 'national interests' leaves the authority of government officials virtually beyond control. The Forestry Law lists a number of rights that apply to recognised customary communities which do, however, not include anything approaching autonomous rights. ${ }^{4}$ From a legal perspective, the scope for local communities to claim ownership or land use rights is thus quite limited.

Decentralisation brought new socially-informed legislation. The year 1998 saw a revitalisation of the 1995 concept of community forestry. ${ }^{5}$ This arrangement allows communities to use forestry areas. The land remains state land but communities receive usage rights for an extended period of time. Community forestry is no recognition of any customary claims whatsoever. In principle, application is open to each community.

Adat (customary) land claims are problematic. ${ }^{6}$ Whereas the New Order government defined many adat communities as 'isolated communities' (masyarakat terasing) cut off from the flow of national development and in need of development assistance (see Persoon, 1998), many of these 'isolated communities' now demand recognition of land claims and adat community (masyarakat adat) rights (cf. Sakai, 2003:252-253; Moniaga, 2007a).

These claims have a legal basis. For instance, a 1999 regulation by the Minister of Agraria/Head of the NLA instructs regional governments to research claims of the recognition of customary communal land (ulayat) and record their findings in a regional regulation. ${ }^{7}$ The regulation defines the conditions that must be met for recognition. Also, the second amendment of the 1945

\footnotetext{
3 The Forestry Department claims to have jurisdiction over $72 \%$ of Indonesia's land (Fay and Michon, 2003:13).

4 See Article 67(1).

5 Decrees 622/Kpts-II/1995 and 677/Kpts-II/1998 respectively. See Kusumanto and Sirait (2000) for a more elaborate discussion.

6 See Bedner and van Huis (2008) for an analysis of adat in Indonesian law.

7 Regulation 5 of 1999.
} 
Constitution, passed in 2000, included two relevant alterations. In Article $18 \mathrm{~B}(2)$, the state recognises and respects individual adat law communities (masyarakat hukum adat), in as far as they are 'still alive' and 'in line with the evolution of society and the unitary state' and national law. Article $28 \mathrm{i}(3)$ offers protection of the cultural identity and rights of traditional communities in accordance with changing times and culture. Both laws are examples of legislation that empower adat-based claims. However, both also illustrate the difficulties as, in both instances, the terms of reference, conditions of validity and decision taking are the exclusive domain of the government.

Although not directly concerned with land, the actual decentralisation laws introduced relevant changes in the autonomy of the regional government and that of the village level. ${ }^{8}$ Adat structures of governance received operating space, although village heads must be elected according to the provisions of local adat, and the scope of village government authority is defined as that which 'already exists based on the rights of origin of the village'. ' As a result, adat gained in official prominence, although it frequently already played an important role in village governance (e.g., Li, 1999; Bakker, 2005). It opened up new opportunities for claiming adat rights to natural resources at the local level. Weak government control allowed villages to mix state and customs in legally ambiguous ways.

In the following sections, we discuss a number of land claims which took place at low levels of government. We show the vast diversity as to how these conflicts were resolved and analyse the diverse formulations of claims, the strategies used and the creative (mis)employment of legal arrangements. In doing so, we aim to obtain an understanding of the multiple ways of gaining access to localities of value. We based our case selection on legal and regional diversity and on the possibility to access and check materials. Also, we diversified in outcomes. Whereas emphasis lies on successful claims, this does by no means mean that a positive result is usual. Three of the cases, those in Lampung (South Sumatra), Garut (West Java) and Wonosobo (Central Java) are not based on adat claims. The others, in Mentawai (West Sumatra), Jambi (South Sumatra), Lebak (East Java), Paser and Nunukan (East Kalimantan) and Lore Lindu (Central Sulawesi) all involve adat in some way. We distinguish three categories of land claims, distinguished on the type of legitimation that is invoked. These are legitimation through: (1) national state institutions; (2) regional autonomy opportunities; and (3) mutual beneficial solutions through extra-legal arrangements.

${ }^{8}$ Notably Laws 22 of 1999 and 34 of 2004.

${ }^{9}$ Law 32 of 2004, Articles 1(12), 203(3) and 206. 


\section{Legitimation through National State Institutions}

The community of Sagara, a village in the district of Garut in West Java, has been engaged in a dispute over land with Perum Perhutani - a state company controlling all production forest in Java — since the 1970s. The Sagara community appealed for permission to farm in the forest and claimed rights dating back to colonial times. According to them, these rights were recognised under the BAL. ${ }^{10}$ Perum Perhatani, however, maintained that the land in question was forest area and under the jurisdiction of the Forestry Department. Perum Perhutani had the support of the local police, various high-ranking military officers and the Governor of West Java, who on occasion resorted to intimidation, destruction of farms and detainment of individuals without due process (see Lukmanuddin, 2002:305-346). Perum Perhutani's claim was disputed by local NLA officials, the Garut district head and, at a later stage, members of the district parliament. After the fall of Suharto, NGO activists and human rights lawyers gave direct support to the community, which eventually led the Forestry Department to recognise the validity of Sagara's historical documents and the community's right to use the land (Bachriadi and Sardjono, 2005:31). It is unlikely that the Sagara community would have arrived at this result without the backing of the NLA or regional government; however, rivalry between these bodies and the national powerhouse (that is, the Forestry Department) worked to the community's advantage.

A similar case is that of the Orang Rimba (literally: 'jungle people', also known as Kubu), a group of some 2,700 individuals who live primarily from hunting and gathering in the forests of Bukit Duabelas, Jambi Province, Sumatra. A large part of these forests is designated as production forest, with smaller parts designated as nature reserves. Together with WARSI, a local environmental NGO, the Orang Rimba attempted in 1984 to get legal protection for all of the Bukit Duabelas area by requesting the Forestry Department to propose the area as a biosphere reserve. ${ }^{11}$ No reply was received, but in 2000 a new Minister of Forestry decided to designate 60,500 hectares of the area as a national park. The decision was promulgated in Ministerial Decree No. 258/ Kpts-II/2000 which underlines the ecological function of the reserve and stresses that it is the living area of the Orang Rimba. Nowhere, however, does the decree mention adat or adat rights but the Orang Rimba and their NGO supporters do feel that it recognises them as masyarakat adat with local land rights. The case is a strong example of a negotiated, quasi-legal result. A ministerial decree has to be consistent with higher laws, in this case especially the

10 The BAL recognises colonial period documents as a basis for valid rights to land.

11 A biosphere reserve is a specific type of conservation designation given by UNESCO. 
Forestry Law. According to the Forestry law, all forest is state possession to which no adat-based ownership rights can exist. The regulation stated that the forest needs to be protected from encroachment by local Malay farmers who claim to have even stronger adat rights to the area. ${ }^{12}$ The alliance between park management and Orang Rimba based on an exclusivist adat discourse protects the forest from an influx of newcomers and safeguards the position of the comparatively small Orang Rimba community, thus serving the needs of both.

However, things do not always go well. Our final example here concerns community forestry. ${ }^{13}$ In late 1999 , a village community in Bandar Lampung (Sumatra) received a temporary community forestry license from the Forestry Department. Regional Forestry Offices followed suit and granted five forest communities licenses to a total of 3,870 hectares of state forest. Throughout 1999-2000, community forestry became a prominent issue in Lampung's forestry politics as officials debated its effectiveness. Cases in other areas, notably in Central Kalimantan, had shown community forestry to be used to legitimise large-scale forest clearance rather than sustainable usage (see McCarthy, 2004). Proponents, however, considered it to be a solution to forestry-related conflicts and forest degradation.

In 2000, Lampung's provincial level Forestry Office promulgated legislation aimed to regulate the licensing of non-timber forest products collection and taxing them. ${ }^{14}$ The regulation was intended as an umbrella law for all forest-related legislation in the province but attracted criticism from lower echelons. Notably, the regulation provides ten-year licenses to harvest nontimber forest products to local communities but provides no legal certainty of use rights. By contrast, the West Lampung district government enacted legislation that explicitly contradicts the province's regulation as it integrates land rights and natural resource management, thus moving beyond the limited usage rights stipulated by the province. ${ }^{15}$ West Lampung thus gives users an incentive to exploit the forest in a sustainable way or to invest in the area. Also, the district regulation lists a number of government responsibilities (and sanctions for not meeting them), thus guaranteeing government support.

West Lampung's legislation is exceptional. Lampung's provincial legislation mainly limits community rights in favour of the government and is likely to instigate right holders to exploit their resources as long as their rights last. Such usage is unlikely to stimulate further development of community for-

\footnotetext{
12 Personal interview with Rudi Syaf, the former executive director of WARSI.

13 This example is largely based on fieldwork by our colleague Myrna Safitri (see Safitri, 2005 and 2007).

${ }^{14}$ Lampung Provincial Regulation 7/2000.

15 West Lampung District Regulation 18/2004.
} 
estry rights in Lampung. By 2009, disagreement over the issue among regional and provincial level Forestry Offices has bogged down community forestry projects throughout the province. Bureaucratic unclarity thus frustrated what could have been a strong form of government-controlled community usage of forest areas.

These three examples show the value of official authorities as allies. They might need allies to oppose other government authorities, as in the rivalry between NLA and Forestry Department in Sagara, or to oppose encroaching outsiders, as in Jambi. Yet the examples also show that it is rarely the authorities who need to enter into commitments to maintain local arrangements. Jambi is an example of cooperative pragmatism to keep outsiders out, even if no official recognition of these rights exists. In Lampung, however, an official disinclination to enter into commitments is clear. Without outside threats, provincial officials prefer to remain detached from the population, even if this frustrates policy efforts at lower levels and does nothing to solve the problem of unregulated usage of forest resources.

\section{Regional Autonomy Opportunities}

The new authorities granted to regional level governments, combined with the direct election of the members of the district parliament and of the district head by the population, made that district populations can now critically assess the merits of their local officials. Despite these political changes, ulayat (communal customary land) claims, have been recognised in only two districts (Lebak in Banten Province, Java, and Nunukan in East Kalimantan). The mixture of state and custom that is official recognition of ulayat claims contains many ambiguous elements. What discourses are used, how is the validity of claims determined, and what does recognition entail? In this part we discuss the processes of ulayat recognition in Lebak and Nunukan, after which we look at unrecognised situations at the village level in Paser (East Kalimantan) and Mentawai (Sumatra) by way of comparison.

The majority of Lebak's population are Sundanese, a population group with a strong ethnic and cultural identity yet consisting of a variety of communities, including the highly traditional Baduy and Kasepuhan groups. The Baduy (who call themselves Urang Kanekes) are probably the best known masyarakat adat in Indonesia. In short, the Baduy number some 5,000 individuals and form a closed community whose adat is governed by the maintenance of religious observances. The Baduy see it as their divine task to maintain the harmony of the earth through stringent observation of their highly elaborate adat, which prescribes rules of governance, farming, housing and clothing. Their 
area, Kanekes, consists of two main parts, inhabited by what are usually called inner (Baduy dalam) and outer (Baduy luar) Baduy. Kanekes is surrounded on all sides by rivers, largely forested, and contains three 'inner Baduy', as well as 51 'outer Baduy' hamlets.

Over the years, lack of empty land has caused neighbouring non-Baduy groups to encroach on Baduy land. The Baduy responded by requesting government recognition of their land rights. As early as 1968, the Governor of West Java took the first step by issuing a decree in which he designated the remaining forest in the Baduy territory as protected forest and thus closed to settlers. ${ }^{16}$ In 1990, the Lebak's district government strengthened the Baduy's position by passing a district regulation on the development of Baduy traditional institutions. ${ }^{17}$ However, these regulations were not enforced and did not stop the influx of outsiders in search of land. The Baduy petitioned government officials and went as far as to express their plight during the annual seba ${ }^{18}$ audiences. In 2000, former President Abdurrahman Wahid visited the Baduy and explicitly expressed his respect for the Baduy, their adat and their role in Indonesian society. Wahid's visit pressured Lebak's district head to enact legislation to protect the Baduy community and their territory (see Moniaga, 2007b). As a result, Lebak passed a regulation on the protection of the Baduy's ulayat right in August 2001. ${ }^{19}$

Yet the Baduy are not the only masyarakat adat in the province of Banten. Some five hours on foot beyond Baduy territory live the Kasepuhan Citorek (hereafter Kasepuhan). The Kasepuhan live in relative isolation and have a culture and adat that closely resemble the Baduy's. But the Kasepuhan are relatively unknown to the outside world. In the 19th century a considerable part of the land claimed by the Kasepuhan as adat land was registered as state forest while individual Kasepuhan registered private rights to smaller plots, which the Indonesian Forestry Department took over as non-state forest areas.

In a recent community mapping exercise facilitated by adat elders and NGOs, the Kasepuhan found that the land they claim as adat territory covers some 7,400 hectares. Individual Kasepuhan can make legal claims of up to 40 per cent of that land based on private NLA certificates and land tax documentation, while the rest remains designated as forest controlled by the Forestry Department. Parts of this area, however, are not forest: they consist of rice fields, fruit gardens, pastures and plantations. Moreover, the area partly

\footnotetext{
16 Governor of West Java Decree No. 2003/B-V/Pem/SK/68.

17 Lebak District Regulation 13 of 1990.

18 'Seba' is an annual tradition in which the Baduy offer some of their harvest to the Bapak Gede (Big Father), usually the Lebak District Head.

19 Lebak District Regulation No. 32 of 2001.
} 
overlaps with the Mount Halimun-Salak National Park (TNGHS), a nature reserve of 113,357 hectares.

The Kasepuhan lack the Baduy's fame and, whereas the land claim of the latter concerns public figures and officials up to the former president, the Kasepuhan lack such support. Throughout the years, low ranking forestry officials have levied 'unofficial tax' on those lands located in the forestry area. Many individuals took a pragmatic stance and paid. ${ }^{20}$ However, land rights under this tax regime were seen as decidedly insecure, which made many individuals hesitant to invest in these lands. After the New Order, the Kasepuhan became more vocal; they held demonstrations and petitioned the district government. In 2004, a coalition of regional adat communities and national NGOs gained a promise from Lebak's chair of parliament to stop unofficial taxation and resolve the overlapping claims and end unofficial taxes. Two weeks later, Lebak's district head sent a letter to the Minister of Forestry. The Kasepuhan, with NGO support, fully exploited the new political situation. They mapped their territories, documented their adat, immersed themselves in state law crash courses and set up a representative organisation which acts as a discussion partner to the local government. In 2009, the legal status of the Kasepuhan land claims was still unclear; nonetheless, the Kasepuhan feel that all support has considerably strengthened their rights and that they are resolved to maintain their claim.

Besides the Baduy, the one other masyarakat adat that has had ulayat claims officially recognised are the Dayak Lundayeh from Nunukan, the northernmost district of East Kalimantan. The Lundayeh mainly live in Krayan, Nunukan's westernmost sub-district. Education and an outward orientation are highly regarded among the Lundayeh and the group nowadays has a comparatively high number of university graduates and professionals. Many of these live outside of Krayan; in East Kalimantan's towns, in Jakarta or elsewhere in Indonesia. ${ }^{21}$ Lundayeh are part of various East Kalimantan police forces and work as civil servants and government officials in many of the province's districts. Nunukan's vice-district head is a Lundayeh, as well as three members of its 25-member district parliament and several senior officials in the district administration: a strong position for an ethnic minority of under ten per cent of the population.

20 Forestry retribution (pungutan kehutana) was collected by Perum Perhutani officials in charge of the area. National park management took over the area in 2006, but some Kasepuhan are still pressured to pay.

${ }^{21}$ The Lundayeh in Krayan number around 10,000 individuals, a similar number is thought to live outside of Krayan. 
In 2003, the district head of Nunukan had research conducted on the existence of hak ulayat in Nunukan. The district head maintained he was impartial towards the hak ulayat question himself but wanted to carry out the instructions that he had been given and clarify the land situation with a view to future development planning.

Using Ministerial Regulation 5/1999, research was conducted into the validity of adat claims in the district. In short, researchers concluded that the Lundayeh use a clear and authoritative adat for managing land and other resources, whereas all other groups, despite their own claims to the contrary, no longer have such a strong adat. The researchers recommended that Lundayeh adat solely should be recorded in a district regulation. The regional government followed these recommendations and formalised Lundayeh ulayat rights in $2004 .{ }^{22}$ Basically the regulation is a formal authorisation of adat authority as it was effective at the time of research; adat authorities are allowed to operate independent of the district government and decide cases pertaining to ulayat land, provided they do not contravene national law. However, no control mechanisms or sanctions are mentioned.

The district regulation was received with indignation among Nunukan's other Dayak groups. Critics argued that the research was used to legitimise existing unpopular development plans, such as the establishment of huge oil palm estates in areas still controlled by inland Dayak groups. These groups maintained that they failed to gain recognition due to sloppy research. As the researchers had not disclosed their subject, the groups had not sufficiently clarified their adat. Moreover, they argued, the Lundayeh's political clout, rather than the actual adat situation, had led to the favourable district regulation.

Interestingly, nearly all of Krayan is designated as forest and hence under the authority of the Forestry Department. This raises serious questions on the district government's authority in recognising ulayat land and adat authority in the area (see also Bakker, 2007).

At the village level of government, regional autonomy-inspired activities take place as well. The village of Madobak, on Siberut, the largest of the Mentawai Islands district in West Sumatra, was largely established in the 1970s, when the Indonesian government resettled a number of local clans (uma) in the village as part of the national masyarakat terasing modernisation efforts. In 2004 , the village head and parliament drafted a village regulation on the management and exploitation of forest resources. The village regulation decrees that issue matters, such as logging, the collection of non-timber forest prod-

${ }^{22}$ Nunukan District Regulation 4 of 2004. 
ucts, cultivation in the forest and hunting, are all subject to local adat and require permission from Madobak's community. It clearly states that the owners of the land and its resources are the uma, whether as group, as family or as individual members. Anyone engaging in any of the aforementioned activities thus needs (written) permission or will incur fines.

Nowhere does the regulation refer to other authorities, such as the National Land Agency or the Forestry Department, although it is more than likely that most of the land and forest surrounding the village is officially under the authority of the Forestry Department. As far as we are aware, this low-level, relatively autonomous form of government has not attracted any complaints from higher authorities. As there is no government organ tasked with checking the legitimacy of village regulations and this task would be extremely difficult for all of Indonesia's countless villages, it seems unlikely that Madobak's arrangements will be contested in the near future.

The final example in this section comes from the village of Kepala Telake in Paser, East Kalimantan's southernmost district. Kepala Telake lies in a densely forested and remote part of the Gunung Lumut Mountains. The community claims an adat territory of some 56,200 hectares of mostly sparsely populated mountain forest. Two official logging companies were operating in the area during Bakker's research in 2005 and 2007. Although they had permits of the Forestry Department, they required local permission as well. In 2002, Kepala Telake's village council had issued a regulation which decreed that every logging operation working in the village's adat territory had to pay a fee per cubic metre to the community. ${ }^{23}$ The amount of the fee was to be determined in mutual deliberation.

Two smaller logging operations were run by people from Kepala Telake themselves. These operations work with village permits and have access to the largest trees and most expensive woods which they remove from the plots designated to the official companies. They laughingly refer to themselves as 'illegal loggers' since the Forestry Department would label them just that; however, in the opinion of the community these people have more rights to $\log$ the local forests than any company with government permits. Both operations are small and provide work to a number of young men. The money made by these villagers and the local sawmills made the community relatively wealthy.

The money paid by the various logging operations is used for community projects. For instance, all houses in the village are connected to a communal generator that provides the village with electricity in the evening. The gasoline

${ }^{23}$ Kepala Telake Village Regulation Number 1 of 2002. 
required, a fee for the machine's operator, and the wages of the two teachers working at the village school make up the community's invariable monthly expenses. Surplus money is used for various one-off projects, such as a pipeline network delivering water to all the houses of the village. Without the logging fees, such projects could not be undertaken and without the village government's interpretation of its authorities under regional autonomy, there would be no logging fees. If the official logging companies would object to the fees and involve higher levels of government, they might save on the fee but they would incur a very poor relation with the community. In turn this would result in the need to hire outside labour and guards for the equipment, which would easily be as expensive. Even if the legality of the regulation is ambiguous, the legal arrangement formalises a working relationship profitable to both sides and offers the necessary legitimation to higher authorities.

The examples in this section show a successful formalisation of already existing informal recognition of ulayat claims for the Baduy and Lundayeh when the authority to do so became accessible to them. The lack of success of the Kasepuhan in this matter indicated the importance of such pre-existing relations and the recognition of indigeneity and distinct cultural differences. Although few communities in Indonesia have been successful in claiming ulayat rights, the autonomy of the more modest administrative level of the village offers opportunities as well. Appeals to official law at this level may act as a vehicle for communities to appropriate official control over 'their' adat resources, as the cases from Madobak and Kepala Telake illustrate.

\section{Extra-legal Arrangements}

Communities regularly enlist the support of local authorities in gaining land arrangements which invoke an aura of legitimacy, yet are, legally speaking, not possible. In the confusing situation of Indonesia's land law, perceived legal status can be as good as the real thing, as some of the preceding cases already indicated. The two cases discussed in this section look at this issue more explicitly.

The first case concerns the Katu people who live in the Lore Lindu National Park in Central Sulawesi. The Katu were living in the area as early as 1910 and feel that their adat rights to the land predate the establishment of the national park. According to the Forest Law, the presence in the park of the Katu and other communities is illegal. Park authorities have proposed various plans for relocation but the communities refused them all as their specific needs and wishes were not taken into consideration. 
In 1997, a local NGO assisted the Katu in mapping their adat. The results were presented to the park authorities and resulted in the first direct talks. In 1999, with post-New Order land reclaiming movements throughout the nation and a weakened government, the head of the park agreed to have the Katu living in the park. The head issued an official letter in which he recognised the existence of the Katu within the park's boundaries and the validity of their adat land rights. ${ }^{24}$ In a book which he published afterwards, the park head described the case as an example of effective collaboration between official authorities and local communities in national park management (Laban, 2007:163-165).

From a legal perspective, a head of a national park does not have the authority to award rights to groups living in that park. He cannot alter the forest status inherent to a national park, or overrule the Forestry Law's instruction that all state forest is managed by the state. Nonetheless, the Katu are satisfied and feel that their rights within the park have been acknowledged. As they did not ask for autonomy or deny state authority over their adat land, they believe that they are not in violation of state law, but instead have secured their interests through legitimate negotiation with the relevant authorities.

Our second case concerns a community of farmers in the district of Wonosobo, Central Java. Wonosobo has shortages of farm land and forests are cleared in order to grow crops. The farming community in our case uses land classified as forest that is managed by Perum Perhutani. The community has a history of settlement in the area and refrains from clearing forest as not to incur problems with the Forestry Department.

Following the weakened control of the state in the immediate post-New Order era, uncontrolled logging by outsiders cleared much of the area's forest, causing extensive flooding. The district parliament, urged by scholars and local NGOs, proposed community-based forest management as a solution. They assumed local people to depend on a healthy forest for their livelihood and to be far less likely to succumb to the seduction of easy logging money. The district parliament passed a district regulation implementing communitybased forest management. ${ }^{25}$ However, the Forestry Department and Perum Perhutani did not agree with the regulation, as it reallocates authority from the Forestry Department to the district government and to local villagers. The conflict became national news when the Minister of Forestry sent a letter to the Minister of Home Affairs questioning the substance of the regulation. ${ }^{26}$

\footnotetext{
24 Letter of the Head of Lore Lindu National Park No. 35/VI-BTNLL.1/1999.

25 Wonosobo District Regulation No. 22 of 2001.

26 See Minister of Forestry Letter No. 1665/Menhut-II/2002.
} 
The situation grew tense. Local farmers and NGOs persistently implemented the district regulation, while Perum Perhutani ignored it. After long debates and consultation sessions, the Minister of Home Affairs decided to cancel the district regulation as it conflicted with higher laws. ${ }^{27}$ Farmers in Wonosobo nonetheless continued to enact the district regulation, whereas a consortium of NGOs appealed at the Supreme Court. The case thus is an example of open conflict in which neither party is willing to give in, or is sufficiently powerful to force the other to comply. Both parties are supported by state authority, so a breakthrough has to come from other arguments.

These two cases discussed show a direct and open contestation of official authority. The permission for the Katu to live in the national park is legally not possible, nor is it possible to continue application of a cancelled regulation, as happens in Wonosobo. With limited enforcement and the support of local officials, however, such situations become possible. An important reason for this is the space provided by the opposition between various representatives of the state who fight one another's policies.

\section{Concluding Remarks}

Law, in Indonesia, is a contested value by itself. Whereas the reformasi effectively ended authoritarian New Order rule, it did not stop bureaucratic authoritarianism, nor smoothly introduced Indonesia's administration and population into a new era of civil society. The meaning, legitimacy and validity of law are prone to contestation and negotiation at the local and national levels. The connection between intention and outcome of actions thus has become significantly more unpredictable from a legal perspective. The value of this ambiguity lies in the various meanings and interpretations that different stakeholders can ascribe to it. Over the last decade, many local groups have attempted to claim rights and formalise essentially illegal practices by using adat law as much as official law. The resurgence of local adat vis-à-vis state law, and masyarakat adat relating their claims to official law stipulations are an example of this. Contestation and power struggle between officials within the state apparatus provide opportunities for local people to do so.

The Forestry Department and the National Land Agency are engaged in a tenacious struggle regarding authority over land which regularly places them on opposite sites in local land conflicts. Forest areas hold the promise of

27 See Decree of the Minister of Home Affairs No. 9/2005. 
resources: whereas land is an immovable locality of value, forest produce can be moved. It is attractive to enterprises, but essential for those eking out a living from, or in, those forests. Regional governments and others attempting to control forest areas thus may find themselves in confrontation with the powerful Forestry Department. However, since decentralisation no department is all-powerful and local forestry officials who are members of local society and engaged in local affairs may well be inclined to engage in negotiation. Circumstances exist under which local government officials consider alternative arrangements more efficient than guidelines from Jakarta bureaucrats. In Sulawesi, for instance, the head of the local national park chose to recognise masyarakat adat claims within the park. Despite the weak legal status of such negotiated results, local parties perceive these as legitimate and valid, legitimising their claims.

The cases discussed above show that the local level arena of land claims is highly dynamic. Local communities use various strategies. They may confront unwilling or hesitant authorities over land claims and convince them of their legal rights (Kasepuhan, the Katu, Wonosobo); quietly work on formalisation of their claims through the agency of government authority or through actual government alliances (Krayan, Mentawai, Paser); or engage in dialogue with the government in order to gain recognition (Baduy, Lundayeh). Local government reactions are diverse as well. Whereas land claims as such are not necessarily supported, governments may deploy supportive initiatives which allow them a certain measure of control (Lampung, Wonosobo). Ultimately, government support is essential. NGOs may facilitate publicity, emancipate and educate local communities, and assist in gaining and uniting support. Yet they have no more legal powers than the communities they assist, and government officials can still successfully withstand such popular pressure. That's why all parties need to gain something.

If anything, the incorporation of government authority in popular attempts at claiming localities is an important and relatively new development. In the recent past of the New Order era, government bodies that controlled, and population groups that claimed rights to land were different and frequently opposed entities that referred to different legitimating discourses. The present and ongoing mixing of the two is not only a sign of popular strategic thinking, it also implies increased knowledge, a more critical stance and a willingness to undertake action among the Indonesian population.

At present the most efficient strategy for local populations to gain rights to land, whether according to formal law, semi-legal agreements or other local arrangements, seems to be through broad local alliances involving other 
communities, NGOs, local parliaments and loyal government bureaucrats. Moreover, when a claiming community has village rights and is located remote from centres of government, it can use village regulations, as well as a lack of supra-local government control, to its own advantage.

The issue of land claims is a highly dynamic one. Obscurities or even inconsistencies in national law, existing social ties between claimants and officials, and power-struggles between different government departments make sure that land claims directed particularly at the lower-levels of bureaucracy stand a chance of success. Whether such success is permanent or temporary, however, is an open question.

\section{References}

Bachriadi, Dianto and Anton Lucas (2002) "Hutan Milik Siapa? Upaya-upaya Mewujudkan Forestry Land Reform di Kabupaten Wonosobo, Jawa Tengah", in Loulena and Yando Zakaria (eds.) Berebut Tanah: Beberapa Kajian Berperspektif Kampus dan Kampung. Anu Yogyakarta: Insist Press and Karsa, pp. 79-158.

Bachriadi, Dianto and Mustofa Agung Sardjono (2005) Conversion or Occupation?: The Possibility of Returning Local Communities' Control over Forest Land in Indonesia. Paper presented through the program of International Exchange in Environmental Governance, Community Resource Management and Conflict Resolution. Institute of International Studies, University of California Berkeley, and the KARSA Foundation (Indonesia).

Bakker, Laurens (2005) "Resource Claims between Tradition and Modernity: Masyarakat Adat Strategies in Mului (Kalimantan Timur)". Borneo Research Bulletin 36: 29-50.

- (2007) "Land administration and hak ulayat. A comparison of policies in the East Kalimantan districts of Paser and Nunukan", in Hans de Iongh, Gerard Persoon and Wawan Kustiawan (eds.) Options for Biodiversity Conservation and Sustainable Use in Lowland Forests of Southeast Borneo. Institute of Environmental Sciences, Leiden University: Leiden, pp. 153-170.

Bedner, Adriaan and Stijn van Huis (2008) "The Return of the Native in Indonesian Law. Indigenous Communities in Indonesian Legislation". Bijdragen tot de Taal-, Land-en Volkenkunde 164(2/3): 165-193.

Fay, Chip and Genevieve Michon (2003) "Redressing Forestry Hegemony. Where a Forestry Regulatory Framework is Best Replaced by an Agrarian One". Paper presented at the International Conference on Rural Livelihoods, Forestry and Biodiversity. Bonn, 19-23 May 2003.

Fitzpatrick, Daniel (1999) "Beyond Dualism: Land Acquisition and Law in Indonesia", in Timothy Lindsey (ed.) Indonesia, Law and Society. Sydney: The Federation Press, pp. 74-96.

Kusumanto, Yanti and Martua T. Sirait (2000) "Community Participation in Forest Resource Management in Indonesia: Policies, Practices, Constraints and Opportunities". South East Asia Policy Working Paper No. 28. Bogor: ICRAF. Available at: http://www.worldagroforestrycentre.org/Sea/Publications/files/workingpaper/WP0046-04.PDF.

Laban, Banjar Yulianto (2007) Pergolakan Konservasi di Palu, Sulawesi Tengah 2000-2002. Bogor. Gunung Halimun Salak National Park Management Project.

Li, Tania Murray (1999) "Marginality, Power and Production: Analysing Upland Transformations", in Tania Murray Li (ed.) Transforming the Indonesian Uplands. Marginality, Power and Production. Amsterdam: Harwood Academic Publishers, pp. 1-44. 
Lucas, Anton and Carol Warren (2003) "The State, the People, and their Mediators: The Struggle over Agrarian Law Reform in Post-New Order Indonesia". Indonesia 76: 87-126.

Lukmanuddin (2002) "Menolak Klaim Perhutani Atas Tanah Rakyat Sagara", in Sapei (ed.) Memecah Ketakutan Menjadi Kekuatan: Kisah-kisah Advokasi di Indonesia. Yogyakarta: Insist Press, pp. 305-346.

McCarthy, John (2004) "Changing to Gray: Decentralization and the Emergence of Volatile Socio-Legal Configurations in Central Kalimantan, Indonesia”. Working Paper 101, Asia Research Centre, Murdoch University.

Moniaga, Sandra (2006) "Ketika Undang-Undang Hanya Diberlakukan pada 39\% Wilayah Daratan Indonesia”. Forum Keadilan (27) 1 November 2006.

(2007a) "From Bumi Putera to Masyarakat Adat: A Long and Confusing Journey", in Jamie Davidson and David Henley (eds.) The Revival of Tradition in Indonesian Politics: The Deployment of Adat from Colonialism to Indigenism. Oxford and New York: Routledge, pp. 275-294.

(2007b) "Between State Laws and District Realities: The Struggle for Customary Land Rights in Upland Banten". Paper presented at Indira Seminar, Universitas Gajah Madah, Yogyakarta, 31 May - 3 June 2007.

Persoon, Gerard (1998) "Isolated Groups or Indigenous Peoples". Bijdragen tot de Taal-, Landen Volkenkunde 154(2): 281-304.

Safitri, Myrna (2005) "Tenure Security, sebuah Arena Pluralisme Hukum di Kawasan Hutan Negara", in Yayasan Kemala (eds.) Tanah Masih di Langit: Penyelesaian Masalah Penguasaan Tanah dan Kekayaan Alam di Indonesia yang Tak Kunjung Tuntas di Era Reformasi. Jakarta: Yayasan Kemala.

- (2007) "Bringing Forest and Law Back to the People: Community Forestry in Lampung, Indonesia". Paper presented at Indira Seminar, Universitas Gajah Madah, Yogyakarta, 31 May-3 June 2007.

Sakai, Minako (2003) "Regional Responses to Resurgence of Adat Movements in Indonesia", in Minako Sakai (ed.) Beyond Jakarta. Regional Autonomy and Local Societies in Indonesia. Adelaide: Crawford House Publishing, pp. 245-269.

Sangaji, Arianto (2000) Orang Katu di Behoa Kakau: Korban Politik Konservasi. Palu: Yayasan Tanah Merdeka.

Supomo, (1953) "The Future of Adat Law in the Reconstruction of Indonesia", in P. W. Thayer (ed.) Southeast Asia in the Coming World. Baltimore: The John Hopkins Press, pp. 217-235. 